<단보>

$$
\begin{gathered}
\text { 황해 참서대(Cynoglossus joyneri) 자어의 형태기 재 } \\
\text { 구선옥·황학진 }{ }^{1} \text { 김진구 } 2 * \\
\text { 부경대학교 생물교육전공, }{ }^{2} \text { 서해수산연구소 자원환경과, } \\
\text { 부경대학교 자원생물학과 }
\end{gathered}
$$

\title{
Morphological Description of Cynoglossus joyneri Larvae Collected from the Yellow Sea
}

\author{
Seon Ok Gu, Hak Jin Hwang ${ }^{1}$ and Jin Koo Kim ${ }^{2 *}$ \\ Biology Education, Pukyong National University, Busan 608-737, Korea \\ ${ }^{1}$ Fisheries Resources and Environment Division, West Sea Fisheries Research Institute, \\ Incheon 400-420, Korea \\ ${ }^{2}$ Department of Marine Biology, Pukyong National University, Busan 608-737, Korea
}

Four specimens of Cynoglossus larvae (3.2-7.3 mm in notochord length, NL) collected from the middle Yellow Sea in August, 2008 were identified as Cynoglossus joyneri larvae based on morphological characteristics; (1) the two elongated dorsal fin rays on the parietal region, (2) protruded abdomen, (3) no melanophores on the mediolateral trunk and tail. Larva of $3.2 \mathrm{~mm} \mathrm{NL}$ is compressed with a little big head and tapering, long tail. Larva of $7.0 \mathrm{~mm}$ NL has 115 dorsal fin and 85 anal fin rays, which are the same to those of adult. Larva of $7.3 \mathrm{~mm}$ NL tended to have concave part in the fringe of forehead, in which left-side eye may move to the other side.

Key words: Cynoglossus joyneri, Larvae, Development, Morphology, Yellow Sea

$$
\text { 서 론 }
$$

참서대과 (Cynoglossidae) 어류는 열 대 및 아열대 해역에 분포하며, 전세계적으로 3속 127종 (Nelson, 2006), 우리나라 에서는 3속 8종만이 보고되어 있다 (Kim et al., 2005). 그 중 참서대 (Cynoglossus joyneri)는 우리나라 서해와 남해, 중국연 안, 발해만, 일본 북해도 이남 등지에 분포하며, 수심 $30 \mathrm{~m}$ 미만의 바닥 모래나 뺄인 지역에 서식한다 (Okiyama, 1988; Kim et al., 2005). 참서대과 어류는 상업적으로 매우 유용한 어종임에도 불구하고 종간 외부형태가 유사하여 생태 연구가 미진한 실정이었으나 (Seo et al., 2007), 자원관리의 필요성에 따라 최근 생태 연구가 활발히 진행 중이다 (Choi et al., 1995; Lee et al., 2000; Baeck et al., 2002; Baeck and Huh, 2004a, $\mathrm{b}, \mathrm{c}$; Seo et al., 2007). 그러나, 이들 연구는 성어에 초점이 맞추어져 산란과 성장을 연구한 것이 대부분이며, 가입에 영 향을 미치는 초기생활기 (Blaxter, 1984)에 관한 연구는 대단히 부족한 실정이다. 일본의 경우 참서대과 어류의 초기생활사에 관한 연구가 참서대 (C. joyneri) (by Minami, 1983), 흑대기 (Paraplagusia japonica) (by Minami, 1982), 개서 대 (Cynoglossus robustus) (by Okiyama, 1988), 용서 대 (Cynoglossus abbreviatus) (by Fujita et al., 1986), 박대 (Cynoglossus semilaevis) (by Wan et al., 2004) 등을 대상으로 활발히 이루어진 바 있다. 그 중 참서대 자치어는 척색장 5.8 $\mathrm{mm}-16.3 \mathrm{~mm}$ 개체를 대상으로 그들의 형태를 보고하였는데 (Minami, 1983), 본 연구에서는 그보다 더 어린 개체가

\footnotetext{
*Corresponding author: taengko@hanmail.net
}

처음으로 채집되었기에 그들의 형태를 상세히 기술하고자 한다.

$$
\text { 재료 및 방법 }
$$

2008년 8월 황해 중부연안에서 봉고네트로 경사인망 중 서대류로 추정되는 자어 4개체 (척색장 3.2-7.3 mm)가 채집되 었다. 외부형태는 입체해부현미경 (Olympus SZH10, Japan) 하에서 관찰하였으며, 몸의 각부위는 Image-Pro plus 2.0 (Media Cybernetics)을 이용하여 $0.1 \mathrm{~mm}$ 단위까지 측정하였 다. 측정이 끝난 개체는 입체해부현미경에 부착된 Camera Lucida를 이용하여 정밀 스케치하였다. 종동정은 Okiyama (1988) 및 Yamada et al. (2007)을, 자치어의 각 부위별 용어는 Russell (1976) 및 Matarese et al. (1989)을 참고하였다. 조사가 완료된 개체는 부경대학교 (Pukyong National University), 어 류학실험실 (Ichthyology Laboratory)에 등록, 보관하였다.

$$
\text { 결 과 }
$$

척색장 $3.2 \mathrm{~mm}$ 자어 (PKU 1678)는 근절고가 척색장의 6.3\% 로 매우 낮았으며, 항문전장은 척색장의 $34.4 \%$ 로 항문이 몸의 앞쪽에 치우쳐 위치하였고, 두장은 척색장의 $18.8 \%$ 에 달하였 다 (Table 1). 눈은 좌우대칭으로 입은 열려 있고 윗턱의 뒤끝은 눈의 뒤끝까지 뻗어 있었다. 모든 지느러미는 막지느러미 형 태로 아직 줄기가 형성되지 않았지만, 두정부에는 길게 신장 된 2 개의 등지느러미 줄기가 관찰되었다. 흑색소포는 나뭇가 지 모양으로 복부의 배쪽 가장자리, 꼬리의 등쪽 및 배쪽 가장 


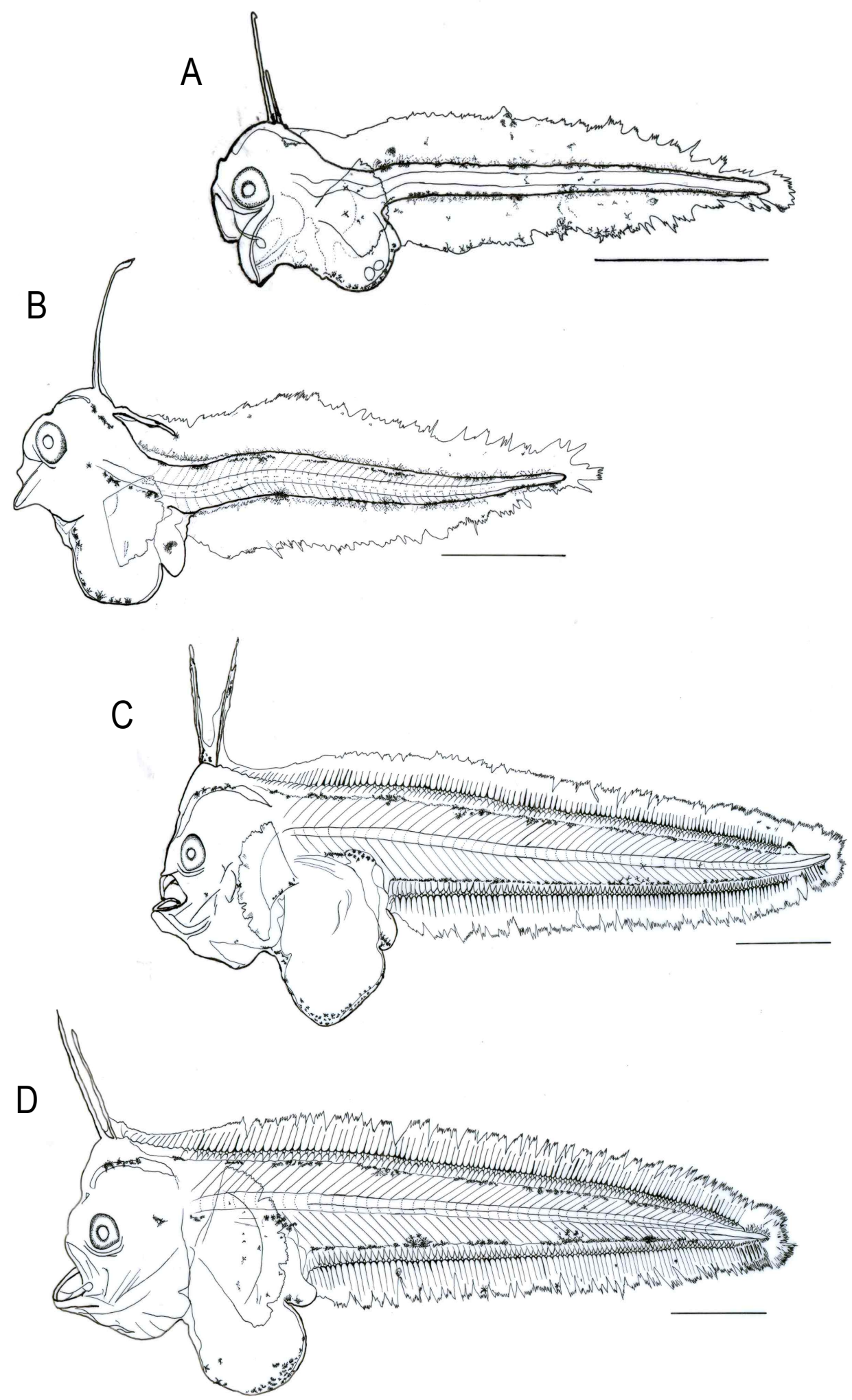

Fig. 1. Morphological development of Cynoglossus joyneri. A: $3.2 \mathrm{~mm}$ NL; B: $4.4 \mathrm{~mm}$ NL; C: $7.0 \mathrm{~mm}$ NL; D: $7.3 \mathrm{~mm}$ NL. Scale bars $=1.0 \mathrm{~mm}$. 
Table 1. Counts and proportional measurements of Cynoglossus joyneri larvae with growth

\begin{tabular}{lcccc}
\hline Specimen number & PKU & PKU & PKU & PKU \\
& 1678 & 1679 & 1680 & 1681 \\
\hline Notochord length $(\mathrm{mm})$ & 3.2 & 4.4 & 7.0 & 7.3 \\
Counts & & & & \\
$\quad$ Dorsal fin rays & - & - & 115 & 114 \\
$\quad$ Anal fin rays & - & - & 85 & 89 \\
$\quad$ Myomeres & - & 44 & 49 & 50 \\
Measurements (In NL) & & & & \\
$\quad$ Head length & 18.8 & 18.2 & 21.4 & 20.5 \\
$\quad$ Myotome height & 6.3 & 6.8 & 14.3 & 16.4 \\
$\quad$ Predorsal length & 15.6 & 15.9 & 14.3 & 13.7 \\
$\quad$ Preanal length & 34.4 & 34.1 & 37.1 & 37.0 \\
$\quad$ Eye diameter & 6.3 & 4.5 & 4.3 & 4.1 \\
\hline
\end{tabular}

자리를 따라 불규칙적으로 무리지어 나타났으며, 막지느러미 와 두정부에도 흔적적으로 관찰되었다 (Fig. 1A).

척색장 $4.4 \mathrm{~mm}$ 자어 $(\mathrm{PKU} 1679)$ 는 소화관 부위가 발달하면 서 복부가 아래쪽으로 돌출하는 경향을 보였고 근절수는 44 개 였다. 두장은 척색장의 $18.2 \%$ 이고, 이 때부터 근절고가 조금씩 커지는 경향을 보였는데 척색장의 $6.8 \%$ 에 달한다 (Table 1 ). 두정부와 복부의 등쪽으로 나뭇가지 모양의 흑색소포가 선명 하게 출현하였고, 꼬리의 등쪽과 배쪽 가장자리를 따라 흑색 소포가 이전보다 뚜렷해졌다 (Fig. 1B).

척색장 $7.0 \mathrm{~mm}$ 자어 (PKU 1680)는 두장이 척색장의 $21.4 \%$ 로 약간 증가하였으며, 항문전장은 척색장의 $37.1 \%$ 에 달하였 다 (Table 1). 이 시기에 등지느러미 줄기가 115 개, 뒷지느러미 줄기가 85 개로 출현하며, 근절수는 49 개로 증가하였다. 꼬리 말단에는 뒷지느러미와 분리된 꼬리지느러미 줄기가 희미하 게 관찰되었다 (Fig. 1C).

척색장 $7.3 \mathrm{~mm}$ 자어 (PKU 1681)는 머리의 앞가장자리의 중간 부위가 오목하게 만입되며, 근절고는 더욱 커져 척색장 의 $16.4 \%$ 에 달하였다 (Table 1). 등지느러미 및 뒷지느러미 줄기는 점차 길어지면서 지느러미 형상을 갖추며 이 시기에 뒷지느러미는 89 개, 근절수는 50 개로 각각 증가하였다. 꼬리 지느러미 줄기는 더욱 신장되며, 뒷지느러미와 꼬리지느러미 사이 간격이 점차 좁아져 그들 사이의 구분이 쉽지 않았다 (Fig. 1D).

\section{고 찰}

2008년 8월 황해에서 처음 채집된 서대류 자어 4개체는 복부가 아래로 심하게 돌출되어 있고, 두정부에는 2 개의 신장 된 등지느러미 줄기가 있으며 등지느러미 115 개, 뒷지느러미 89 개를 가지는 점에서 참서대의 자어로 동정되었다. 일반적으 로 서대류 자어는 소화관의 발달과 함께 복부가 아래로 돌출 되며, 특히 두정부에는 길게 신장된 1-2개의 등지느러미 줄기 를 가진다 (Blaxter, 1984; Okiyama, 1988; Yamada et al., 2007). 서대류 중 용서대, 개서대, 박대는 1 개의 신장된 등지느러미
줄기를 가지는 반면, 참서대, 물서대 (Cynoglossus gracilis), Cynoglossus itinus, 흑대기는 2개의 신장된 등지느러미 줄기를 가지는 것으로 알려져 있다 (Minami, 1982; Minami, 1983; Fujita et al., 1986; Okiyama, 1988; Wan et al., 2004; Yamada et al., 2007). 2개의 신장된 등지느러미 줄기를 가지는 서대류 가운데 등지느러미 115 개, 뒷지느러미 89 개를 가지는 종은 참서대 (D. 107-116; A. 85-90)와 흑대기 (D. 106-117; A. 84-92) 2종 뿐이다 (Yamada, 2002). 그러나, 흑대기는 $5.95 \mathrm{~mm}$ 자어에 서 체측 중앙에 긴 띠 모양의 흑색소포를 가지는 점에서 참서 대 자어와 잘 구분되었다 (Minami, 1982; Blaxter, 1984). 일본 산 참서대 자어는 척색장 $9.6 \mathrm{~mm}$ 에서 등지느러미와 뒷지느러 미가 앞쪽에서 뒤쪽 방향으로 분화되는 반면 (Minami, 1983; Okiyama, 1988), 황해산은 척색장 $7.0 \mathrm{~mm}$ 에서 두 지느러미가 앞뒤로 동시에 분화되는 점 (Fig. 1C)에서 달랐다. 본 연구에서 참서대 자어는 2008년 8월 말에 채집되었는데, 참서대가 6-7 월에 산란하고 8월에 자어를 채집할 수 있다는 기존의 보고 (Chyung, 1977; Choe et al., 1995; Baeck and Huh, 2004b; Kim et al., 2005)와 잘 일치하는 것이다.

\section{사 사}

본 연구는 국립수산과학원 서해연안어업자원조사 (인증번 호: RP-2009-FR-051)의 지원에 의해 수행되었으며 이에 감사 드립니다.

\section{참고문헌}

Baeck GW and Huh SH. 2004a. Age and growth of three-lined tonguefish (Cynoglossus abbreviatus) (Soleidae; Teleostei). J Kor Fish Soc 37, 51-56.

Baeck GW and Huh SH. 2004b. Age and growth of red tongue sole (Cynoglossus joyneri) in the southern sea of Korea. J Kor Fish Soc 37, 307311.

Baeck GW and Huh SH. 2004c. Feeding habits of robust tonguefish, Cynoglossus robustus collected in the coastal waters of Yosu, Korea. Kor J Ichthyol $16,341-347$.

Baeck GW, Huh SH and Hashimoto H. 2002. Feeding habits of tonguefish, Cynoglossus joyneri collected in the coastal waters off Yosu, Korea. Kor J Ichthyol 14, 234-239.

Blaxter JHS. 1984. Ontogeny, Systematics and Fisheries. In: Ontogeny and Systematics of Fishes. Moser HG, ed. Special Publication Number 1, American Society of Ichthyologists and Herpetologists, Lawrence, 1-760.

Choi Y, Kim IS, Park JY, Chung EY and Ryu BS. 1995. Ecology of Cynoglossus joyneri Gunther from the western coast of Korea. Kor J Ichthyol 7, 56-63.

Chyung MK. 1977. The Fishes of Korea. Il-ji Publishing, 
Seoul, 1-727.

Fujita S, Kitajima C and Hayashida G. 1986. Induction of ovarian maturation and development of eggs, larvae and juveniles of the tonguefish, Cynoglossus abbreviatus, reared in the laboratory. Japan J Ichthyol 33, 304-315

Kim IS, Choi Y, Lee CL, Lee YJ, Kim BJ and Kim JH. 2005. Illustrated Book of Korean Fishes. KyoHak Publishing, Seoul, 1-615.

Lee JS, Kim SY, Ma KH and Huh SH. 2000. Ovarian development and reproductive cycle of the female red tongue sole, Cynoglossus joyneri (Teleostei : Cynoglossidae). J Kor Fish Soc 33, 554-558.

Matarese AC, Kendall Jr AW, D.M. Blood and Vinter BM. 1989. NOAA Technical Report NMFS 80 Laboratory Guide to Early Life History Stages of Northeast Pacific Fishes. U.S. Department of Commerce, USA, 1-652.

Minami T. 1982. The early life history of a tongue fish Paraplagusia japonica. Bull Japan Soc Sci Fish 48, 1041-1046.

Minami T. 1983. The early life history of a tongue fish Cynoglossus joyneri. Bull Japan Soc Sci Fish 49, 719-724.

Nelson JS. 2006. Fishes of the World. 4th ed. John Wiley \& Sons Inc, Canada, 1-601.
Okiyama M. 1988. An Atlas of the Early Stage Fishes in Japan. Tokai University Press, Tokyo, 1-1157.

Russell FS. 1976. The Eggs and Planktonic Stages of British Marine Fishes. Academic Press, London, 1524.

Seo YI, Kim JI, Oh TY, Lee SK, Kim ST and Joo H. 2007. Age and growth of the robust tonguefish, Cynoglossus robustus in the southern sea of Korea. Kor J Ichthyol 19, 324-331.

Wan RJ, Jiang YW and Zhuang ZM. 2004. Morphological and developmental characters at the early stages of the tonguefish Cynoglossus semiliaevis. Acta Zoolog Sin 50, 91-102

Yamada U. 2002. Cynoglossidae. In: Fishes of Japan with Pictorial Keys to the Species. English ed. Nakabo T, ed. Tokai University Press, Tokyo, Japan, 1388-1392.

Yamada U, Tokimura M, Horikawa $\mathrm{H}$ and Nakabo T. 2007. Fishes and Fisheries of the East China and Yellow Seas. Tokai University Press, Kanagawa, 1-1262.

2009년 11월 6일 접수

2009년 11월 24일 수정

2009년 12월 18일 수리 